\title{
農薬製剤研究の新しい動向
}

\section{A New Trend of Pesticide Formulation Research}

\author{
和田譲* \\ Yuzuru WADA
}

\begin{abstract}
Key Words : Pesticide Formulation, Pesticide Application Method, Compartment Model, Suspension Concentrate, Emulsion Concentrate, Water Dispersible Granule
\end{abstract}

1.はじめに

農薬が施用されてから，標的生物に達し，効果を発 揮するまでの段階を、整理して示す1)。

(1) 農薬製剤を散布する。

（2）散布された農薬製剤が保護すべき作物集団に到 達する。

(3) 製剤から有効成分が放出される。

（4）放出された有効成分が標的生物まで輸送される。

（5）標的生物が有効成分を取り込む。

以上の各段階を医薬の場合之比較して見る。農薬 之医薬の間で最も異なるのは，(1)，(2)の段階であ る。医薬は人の各個体に直接投与される。各個体は, 閉鎖系と考えることができる。一方農薬は開放系に散 布される。したがって，（a）散布中に農楽の何割かが 目標域外に漂流する,（b）散布された農薬が, 揮散, 流亡などにより，域外に輸送される。などの問題があ る。乙れは環境問題と直接かかわると同時に，農薬の 利用率を低める。

\section{昭和 62 年 9 月 2 日受付 \\ *日本特殊農薬製造 (株) 農薬研究所製剂研究部 \\ (T193 八王子市並木町 5-1) \\ TEL 0426-61-5275}

$$
\text { 〈著者紹介〉 }
$$

昭和 10 年 秋田県に生まれる

昭和 39 年 東京農工大学農芸化学科卒業 日本特殊農薬製造（株）に入社

昭和 57 年 第 6 回国際農薬学会シンポジウムパネリスト 昭和 60 年 第 7 回国際農薬学会招待講演者

\section{2. 農薬製剤}

表 1 に示したように, 農薬製剤は Field strength formulations（そのまま撒く製剂）と Concentrates に分けられる。英語名のみをしぬした製剤は，日本語の 定訳がないと考えたものである。他の分類基準によれ ば，固体製剤と液体製剂とになる。例外として，固体 微粒子が液体に分散している粕濁剂がある。これは両 者の合の子である。

粉剂は，おもにクレーをキャリヤーとし、農薬原体 と添加剂を混合した剂である。 $40 \mu \mathrm{m}$ 以下の粉末で， 中位径が $10 \mu \mathrm{m}$ 前後である。粉剤を散布すると, 漂流 が多く，環境污染および作業者の被曝の点から批判さ れた。数年前から，微粉部分を除いたキャリャーを用 い, 中位径が $20 \mu \mathrm{m}$ 以上で，漂流が少ない DL 粉剂 (Drift less)が普及している。

粒剂は粒子径が $10 〜 48$ meshの範囲に属する剤で ある。大部分の水田除草剤は粒剂の形で使われている。 殺虫剂や殺菌剂は，おあに，吸収移行性を持っている ものが粒剂化される。吸収移行性之は，作物の根など から取り込まれた農薬が茥葉に移行する性質を言う。 粉剂を散布すると有効成分が直接䒱葉に寄生する病害 虫と接触する。粒剤の場合は農薬がマトリックス中に 分散しているので, 施用したとき直ちに有効成分が病 害虫に接触することはない。いったん有効成分が水田 水中などに溶出し，それが標的生物まで輸送される。

水和剂は, 中位径を $4 \sim 5 \mu \mathrm{m}$ 程度に微粉砕した農 薬原体を，湿潤剂，分散剂および微粉クレー $(5 \mu \mathrm{m}$ 以

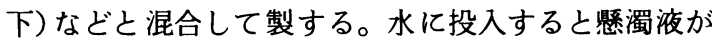
得られる。 


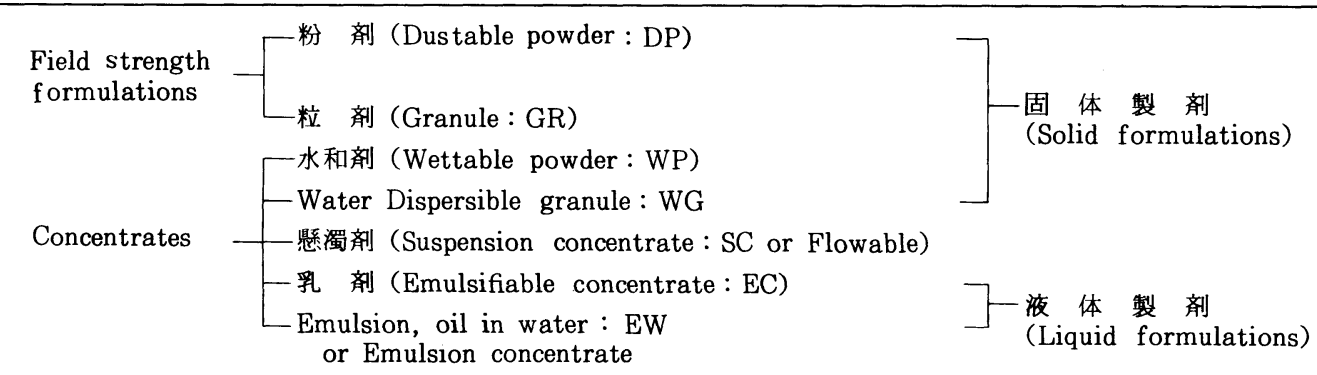

乳剤は農薬原体を適当な有機溶剂（キシレンが使わ れる場合が多い）に溶かし，乳化剤を加えた製剤であ る。水に投入するとエマルションになる。

近年欧米を中心に，水和剤之乳剂が批判され始めて いる。両剤とも，製造コストが安く，一般に眝蔵安定 性がよい。その上，防除効果あ一応満足できる剤型で ある。しかし，水和凨は微粉なので，薬液を調製する とき粉立って, 散布作業者が被曝する。乳剂には, 蒸気 圧の高い溶剤が含まれていて，散布作業者が被曝する だけでなく，広く環境を污染する恐れがある。

ての両剤が持つ欠点を除いた製剤として, 水を媒質と する懸濁剤とEmulsion concentrates がある。しか し、乙れらの分散系製剂は, 眝蔵安定性が水和剂や乳 剤ほよ゙良くない。分散系製剤を安定化するための、レ オロジカルな理論および実験結果が多数報告されてい $3^{2 \sim 4)}$ 。

固体農薬で眯濁剤に調製できないあのはWater dispersible granules (WGs) 亿調製 ${ }^{5}$ する。WGsは水和 剂を顆粒化したあので，粉立ちの欠点がない。顆粒化 法として, 喷蓩造粒法, 流動層造粒法, 転動造粒法 押し出し造粒法が報告されている6 8)。

農薬製剂の新しい動向は，乳剤および水和剤を懸濁 剂, Emulsion concentrates, WGs に切り替えるこ とである。

\section{1 懸 濁 荗}

Gueckel ら ${ }^{9)}$ は, 眯濁剂が安定に分散し得る上限温 度(Upper limit of stability：ULS)を測定した(図 1)。ULSを越えると，㲘濁している粒子が不可逆的 に凝集する。表 2 の Herbatox眯濁剂では，粒子径が 細かくなるほどULS が低下し，中位径 1.4，1.6 $\mu \mathrm{m}$ のとき $36^{\circ} \mathrm{C}, 42^{\circ} \mathrm{C}$ になった。乙れは，夏期に実現す る温度である。表 3 は, chloridazon 奬濁剤において 固体濃度と増粘剤濃度が ULS に及ぼす影響を示す。 chloridazon 濃度が高くなるとULS が低下し, 增粘 剂の添加量を増やしてもULS は改善されない。

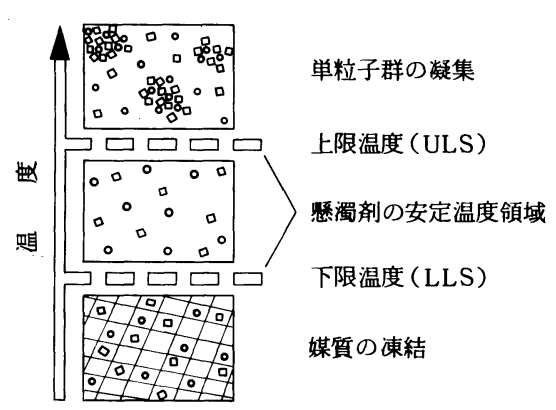

图 1 㲜濁剤が安定な上限及び下限温度

表 2 Hebatox懸濁剤の中位径とULS

\begin{tabular}{|c|c|c|c|c|}
\hline 粉砕回数 & $\begin{array}{c}\text { RRSB 分布にお } \\
\text { げる中位径 } \\
{[\mu \mathrm{m}]}\end{array}$ & $\begin{array}{c}\text { 粘 度 } \\
{[\mathrm{mPa} \cdot \mathrm{s}]}\end{array}$ & $\begin{array}{l}\text { ULS } \\
{\left[{ }^{\circ} \mathrm{C}\right]}\end{array}$ & $\begin{array}{l}\text { 結晶成長の } \\
\text { 傾 向 }\end{array}$ \\
\hline 1 & 2.8 & 136 & 78 & \\
\hline 2 & 2.3 & 185 & 61 & \\
\hline 3 & 1.9 & 210 & 56 & \\
\hline 4 & 1.7 & 232 & 52 & \\
\hline 5 & 1.6 & 256 & 42 & \\
\hline 6 & 1.4 & 295 & 36 & $\downarrow$ \\
\hline
\end{tabular}

Tadras ら山は, キサンタンガム十アエロジル系とキ サンタンガム+ベントナイト系のいずれが眯濁剤の安 定化江有利かを試験した。図 $2 ， 3$ 亿明らかなように， キサンタンガム十アエロジル系では $\gamma_{\beta}$ (ビンガム降伏 值) と $G_{\infty}$ (高周波弾性率)が, キサンタンカム十ベントナ イト系より高く，その上前者では両パラメーターとあ $\mathrm{pH}$ 依存性であり, pH5でゲル化する。 $\gamma_{\beta}$ と $G_{\infty}$ が 高いのは，キサンタンガムとアエロジルの相互作用が 強いととを示している。相互作用がマイルドな, +べ ントナイト系の方が, 懸濁剤の安定化には適している とした。

分散質が分散媒に 100 ppm以上溶解すると, Ostwald ripening が起こり, 安定な懸濁剂ができないとされ ていた。Synek ${ }^{10)}$ は, 毒性の点で心配のない Propan- 
Chloridazon懸濁斉の有効成分量および増粘剂量と ULS

\begin{tabular}{cccl}
\hline $\begin{array}{c}\text { 有効成分含量 } \\
{[\mathrm{g} / l]}\end{array}$ & $\begin{array}{c}\text { 増粘剤の濃度 } \\
{[\mathrm{g} / l]}\end{array}$ & $\begin{array}{c}\text { 粘 度 } \\
{[\mathrm{mPa} \cdot \mathrm{s}]}\end{array}$ & $\begin{array}{l}\text { ULS } \\
{\left[{ }^{\circ} \mathrm{C}\right]}\end{array}$ \\
\hline 100 & 0 & 3.6 & 65 \\
200 & 0 & 5.6 & 63 \\
400 & 0 & 23.5 & 52 \\
500 & 0 & 36.8 & 54 \\
\hline 100 & 2 & 16.0 & 66 \\
200 & 2 & 24.1 & 62 \\
400 & 2 & 55.8 & 53 \\
500 & 2 & 85.9 & 47 \\
\hline 100 & 5 & 34.6 & 66 \\
200 & 5 & 48.6 & 57.5 \\
400 & 5 & 105 & 47.5 \\
500 & 5 & 160 & 41
\end{tabular}

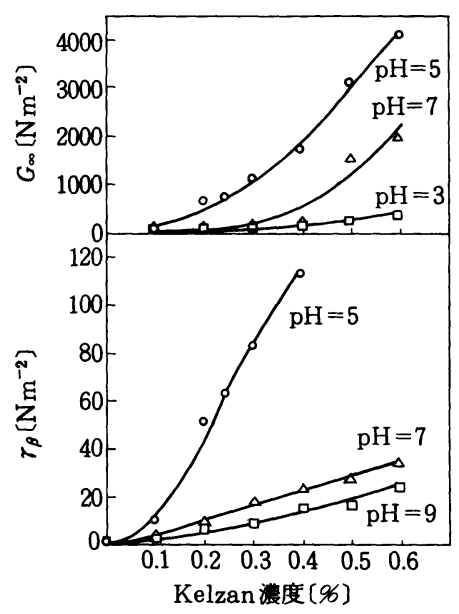

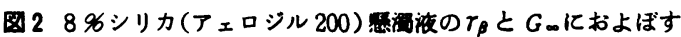
キサンタンガム(Kelzan) 湍度および $\mathrm{pH}$ の影要

diol 媒質とし， azinphos methyl の安定な彩濁剤 の調製に成功した。 azinphos methyl は Propan-

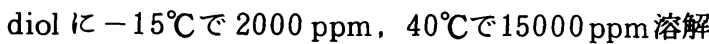
する。表 4 亿処方の概略を示す。重要な点を列挙する。 (1) 粒子径を $10 \mu \mathrm{m}$ 程度にする ( $<1 \mu \mathrm{m}$ の粒子は, 固 化を促進する),（2）azinphos methyl の仕込量 (固 体濃度）を一定にする，(3) 分散剤リグニンスルホン 酸ソーダと湿潤剤のバランスが少しずれてあ，凝集が おてる，(4) 酸度の上昇を微アルカリ性シリカを加え て抑える，（5）シリカとリグニンスルホン酸を共用す ると, azinphos methyl の結晶成長が抑えられる。

2. 2 Emulsion Concentrates(潂厚エマルション剂) Roechling ら ${ }^{11}$ は，経皮毒性の強い 殺線虫剂 $\mathrm{HOE}$

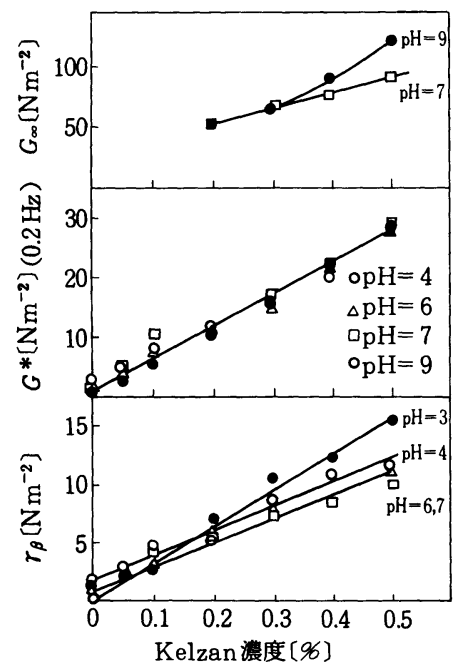

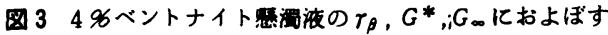
キサンタンガム(Kelzan) 湍度および pH の影要

表 4 Azinphos methyl 急濁阂の処方

\begin{tabular}{l|c}
\hline Azinphos methyl 原体(90\%) & 農 蒋 \\
\hline プロパンジオール & 媒 質 \\
\hline シリカ & 安定化剂 \\
\hline カオリン & 安定化剂 \\
\hline リグニンスルホン酸塩 & 分 散 剂 \\
\hline アルキルアリルスルホン酸塩 & 湿 潤 剂 \\
\hline
\end{tabular}

36275, O-ethyl-S- (N-phenyl-N-methyl-carbamoyl-methyl)-isopropylamido-thiophosphate, のミクロエマルション製剤を調製し，急性経皮毒性を， 2 種の乳剤と比較した。ミクロエマルション製剤の 毒性がきわめて低いととが分かる。

$$
L D_{50} \quad \text { ラット, メス }
$$

$40 \mathrm{EC}$ in Solvesso 200

$57.5 \mathrm{mg} / \mathrm{kg}$

$40 \mathrm{EC}$ in methyldiglycol $282.2 \mathrm{mg} / \mathrm{kg}$

$200 \mathrm{~g} / \mathrm{L}$ EW(microemulsion) $\quad 2000.0 \mathrm{mg} / \mathrm{kg}$ 辻ら ${ }^{12)}$ は、スミサイジンをマクロエマルション剤に 調製した。同剤のマウスに対する経口急性毒性とウサ ギの眼に対する刺激性を、乳剂と比較した。

$$
\begin{aligned}
& \text { 経口 } / L D_{50} \text { 眼/刺激 } \\
& {[\mathrm{mg} / \mathrm{kg}]}
\end{aligned}
$$

$$
\begin{array}{lrrl}
\text { スミサイジン E W } & >5000 & >5000 & \text { な し } \\
\text { スミサイジン乳阂 } & 330 & 300 & \text { 中程度 }
\end{array}
$$




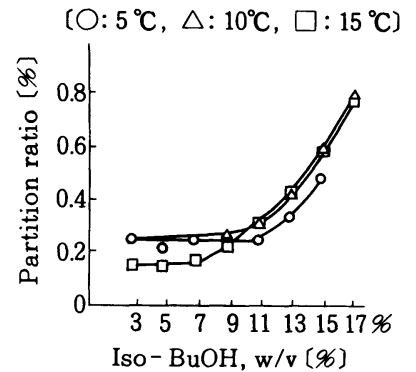

図4（a）3\% SDS 溶液中でのイソブ タノールのミセル・バルク水 間分配率

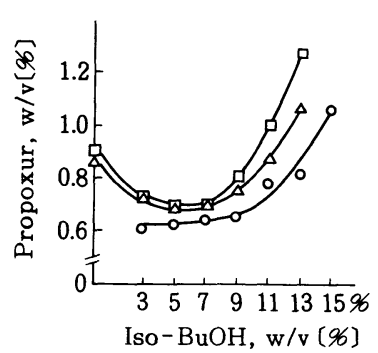

(b) SDS 3\%,イソブタノール0 〜15\%および水の系に対する プロポクスルの溶解量

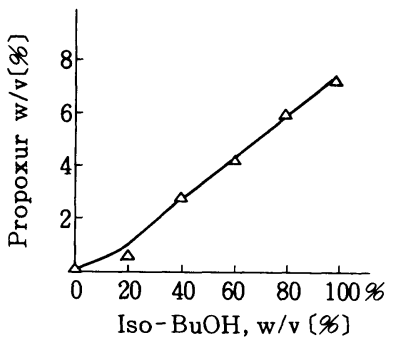

(c) nードデカンにイソブタノール を加えた系に対するプロポク スルの溶解量

\section{3 Emulsion Ready for Use(使用灌度エマルション剂)}

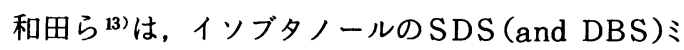
セルとバルク水間での分配率，およびその系に対する 殺虫剂プロポクスルの溶解度を測定した。図4(a)に 示すように, イソブタノールのミセルーバルク水間 分配率は、イソブタノールの添加量が $8 \%$ あたりまで は一定であるが，それを越えるとミセルへの分配率が 急激に高くなる。乙の系にプロポクスルを加えると， イソブタノールが $8 \%$ 以下の間は，イソブタノール濃 度が上がるにしたがい，プロポクスルの溶解度が低くな る(図 4(b))。しかし，図4（a）の届曲点之ほぼ同じ所 から、プロポクスルの溶解が急激に高まる。以上の事実 を考察する。初めイソブタノールとプロポクスルは競合 してミセルのパリセイド層に入るが，イソブタノールの 方が優先的に取り込まれる。イソブタノールが水に対す る飽和量以上になると，以後ミセル内部の蹯水部に入る。 その結果, ミセルの内部の極性が高くなり, 内部にプ ロポクスルを溶かし得るようになる。ミセルの疎水部 のモデルとしてnードデカンを選び，イソブタノール を加えてプロポクスルの溶解量を測定した。図4(c) に示すように，イソブタノールの添加量に比例してプ ロポクスルの溶解量が増加した。

\section{3. 農薬の散布}

農薬の有効成分は 10 アール $\left(1000 \mathrm{~m}^{2}=\right.$ 一反 $)$ 当り 数十グラムから百数十グラム散布すれば，充分効果を 発現するあのが多い。近年開発された，あるいは開発 されつつある剤の中には，乙の $1 / 10$ さらには $1 / 100$ で利くあのがある。

日本では, 粉剤と粒剂は 10 アール当り $3 \mathrm{~kg}$ 散布す るのが標準である。逆に言うと， $3 \mathrm{~kg}$ 散布すれば充分 効果がでるように，製剤の有効成分含量を定める。 concentrates は水で1000倍に希釈し，10アール当り
100 リットル散布する。以上は,地上散布の場合である。 ヘリコプターで散布(航空散布)する場合は，三段階 の散布量がある：へクタール当り 30 リットル，8 リッ トル，数百ミリリットル。乙れらを $\mathrm{S}$ 散布，LV散布 (Low volume spray), ULV散布(Urtra low volume spray）とよぶ。航空散布では，一回の飛行で，でき るだけ広い面積に散布し，経済性を上げる。したがっ て, 地上散布より濃い散布液を, 単位面積当り少量散 布する。

農薬は散布されると，一部は目標域外に漂流する。 目標域に落下した農薬も，病害虫などに到達するまで に，揮発，分解，分配、流亡などにより損失する。 Pimentel ら ${ }^{14)}$ は, 農薬が標的生物に到達する量が $0.1 \%$ に満たないととが多いとし, 散布法の精密化に よりせめて現在の散布量を半分まで減らすことを期待 している。

Maybank ${ }^{15)}$ が指摘しているように, 散布された農 薬の分布は均一ではない。防除効果を上げるには，分 布の最む少ない場所にも十分な農楽が行き渡らなりれば ならない。裏返して考えれば，ほとんどの部分に過剩 量の農薬が散布されている。

害虫集団の中の各個体が, 散布された農薬の液滴之 接触する確率が等しいと仮定する。乙のとき，害虫が 接触する液滴数の相対確率は, ポアソン分布に従う ${ }^{16}$ 。 一匹の害虫が $r$ 個の液滴と接触する確率は, $n^{r} \cdot \exp$ $(-n) / r$ ! となる。 $n$ は平均の接触個数である。 $n=1$ のとき， $0,1,2 \cdots \cdots$ 個が一匹の害虫之接触する確率 は $37 \% ， 37 \% ， 26 \%$ となる。一滴がちょうど致死量 の農薬を含むとすれば， $37 \%$ の農薬は無駄なく利用 され，37\%は害虫と全く接触せず無駄になり，26\% は複数滴接触するので過剩投与になる。液滴径を小 さくするか，散布液量を増して液滴数を多くし， 8 滴 (平均接触個数) が致死量に相当するようにすると， 
表 5 液滴数之防除効率一各殺虫剂量と接触する害虫の 比率 $[\%]$

\begin{tabular}{c|c|c|c}
\hline 平均接触液滴数 & 致死量 & 致死量以下 & 過剩量 \\
\hline 1 & 37 & 37 & 26 \\
\hline 4 & 55 & 24 & 21 \\
\hline 8 & 79 & 10 & 11 \\
\hline
\end{tabular}

$79 \%$ の農薬が無䭾なく利用される(表 5)。しかし, 散布量を多くすれば, 小量散布の経済性が損われるし， 液滴径を小さくして数を增やせば, 漂流が多くなる。 結局どてかで妥協するてとになる。

\section{4. 水田での農薬の動態}

Crossland ${ }^{17)}$ らは, 水系における化学物質の消長に 関し, 人工池などでの実験値と数学モデルからの推定 值が，よく一致したと報告している。

鈴木ら ${ }^{18}$ は, 水田水中での除草剂濃度を経時的に測 定し，片対数グラフ用紙にプロットした（横軸一日数。 縦軸一水中濃度)。結果は二時点で勾配が変わる折れ 線になった。乙の減衰を数式化し，三つの指数関数の 和になるととを示した。

和田ら ${ }^{199}$ は，水田除草剂メフェナセットの各種製剂 を，モデル水田に施用し，水中除草剂濃度を経時的に 測定した。実験に用いた製剂は, 乳剂 (EC) と有効成 分溶出速度の異なる三種類の粒剂である。図 5 亿明 らかなように, 乳羭区の濃度は急激に単調減少し, 粒区剂はいずれも，濃度の極大值を形成した。粒剂の なかでは $\mathrm{GR}-\mathrm{A}$ が最も溶出が速く, 濃度減少も乳剂に ついで速い。溶出速度が最も遅い GR-Cは長い期間安 定した濃度を保っている。和田 ${ }^{1)}$ は水田における以上 のような農薬の消長を、コンパートメントモデルで説 明した。

水田を, 水と底質の二つのコンパートメントのみに 単

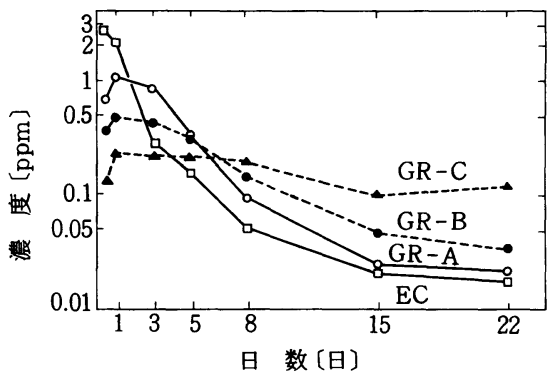

図 $5 \times$ フェナセット製剤を施用したモデル水田 水中での有効成分の消長

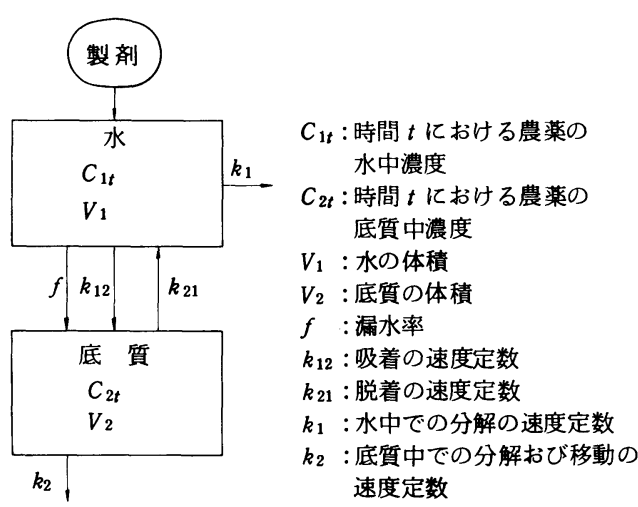

図 6 水田のコンパートメントモデル

表 6 水田モデルの寸法

水 $100 \mathrm{~m} \times 100 \mathrm{~m} \times 0.05 \mathrm{~m}=5 \times 10^{2} \mathrm{~m}^{3}$

底 質 $100 \mathrm{~m} \times 100 \mathrm{~m} \times 0.05 \mathrm{~m}=5 \times 10^{2} \mathrm{~m}^{3}$

純化(図 6)する。水と底質のディメンションを表 6 亿 しめす。底質の $5 \mathrm{~cm}$ より深い部分は系外とする。す なわち， $5 \mathrm{~cm}$ 以内の底質から系外に物質は移動する が, 逆の移動はないあのと考える。各コンパートメン 卜内部で化学物質の濃度勾配はなく, 物質の移動, 分 解などが全て一次速度式にしたがうとすると，図6亿 対応して次の連立微分方程式が成立する。

$$
\begin{aligned}
& \mathrm{d} C_{1 t} / \mathrm{d} t \\
& \quad=(\text { 農薬供給 })-\left(k_{12}+f+k_{1}\right) C_{1 t}+k_{21} C_{2 t} \cdot\left(V_{2} / V_{1}\right)
\end{aligned}
$$

$$
\begin{aligned}
& \mathrm{d} C_{2 t} / \mathrm{d} t \\
& \quad=\left(k_{12}+f\right) C_{1 t} \cdot\left(V_{1} / V_{2}\right)-\left(k_{21}+k_{2}\right) C_{2 t}
\end{aligned}
$$

他の実験から水中のメフェナセットが土壤（東京 都日野市の水田から採取) 亿吸着される半減期を約 0.5 日と推定した。したがって $k_{12}=0.693 / 0.5=1.386 /$

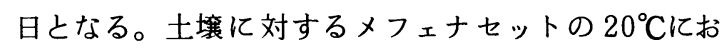
ける吸着等温線から ${ }^{19}$ 吸着係数 $K d$ を 32.7 之読む。し たがって， $k_{21}=k_{12} / k_{d}=0.042 /$ 日 $(1.386 / 32.7) 。$ 漏水率 $f$ (水田から地下に水が漏れる)を $0.200 /$ 日 する。他の常数をメフェナセットの, 残留・代謝実験 の結果から， $k_{1}=0.0693 /$ 日, $k_{2}=0.1286 /$ 日と推定 した。有効成分施用量は水田モデル $(100 \mathrm{~m} \times 100 \mathrm{~m} \times$ $0.05 \mathrm{~m}$ ) 当り $1735 \mathrm{~g}$ とする。

製剤の有効成分の溶出 (放出) 型を三種類とする： （a）水田水中の初期濃度が $1735 \mathrm{~g} / 500 \mathrm{tons}=3.47$ ppm となる One shot型(乳剂型)，(b)毎日 $1735 \mathrm{~g} /$ 5 日 $=345 \mathrm{~g} /$ 日の一定速度で溶出する 0 次溶出型 
( sink 条件でのマイクロカプセル型)，(c)半減期が 三日の 1 次溶出型 ( $\operatorname{sink}$ 条件で，溶出速度が製剂中の 有効成分濃度に比例する)。

(b) の溶出型について微分方程式を例示す。

$$
\begin{aligned}
\mathrm{d} C_{1 t} / \mathrm{d} t= & 345 / 500 \\
& -(1.386+0.200+0.0693) C_{1 t} \\
& +0.042 C_{2 t} \\
\mathrm{~d} C_{2 t} / \mathrm{d} t & \\
=(1.386 & +0.200) C_{1 t}-(0.042+0.1286) C_{2 t}
\end{aligned}
$$

ラプラス変換して解を求める。

$$
\begin{aligned}
C_{1 t}= & 0.5396-0.3967 \cdot \exp (-1.699 t) \\
& -0.1429 \cdot \exp (-0.1336 t) \\
C_{2 t}= & 4.741+0.4143 \cdot \exp (-1.699 t) \\
& -0.1429 \cdot \exp (-0.1336 t)
\end{aligned}
$$

ただし，5日目で製剤中の有効成分はなくなるので, それ以降は減少だけになる。

$$
\begin{aligned}
C_{1 t}= & 0.07055 \cdot \exp (-0.1336 t) \\
& +0.3968 \cdot \exp (-1.699 t) \\
C_{2 t}= & 2.550 \cdot \exp (-0.1336 t) \\
& -0.4126(-1.699 t)
\end{aligned}
$$

図７亿水中濃度を，図８亿底質中濃度をプロットし た。図 5 の水中実測濃度のプロットと比較すると，実 線が乳剂に，点線が粒剂に良く対応していることがわ かる。

\section{引用 文 献}

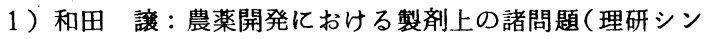
ポ), p. 62 (1983)

2) Tadros, Th. F. :"Pesticide Chemistry (5th ICPC*)", Vol. 4, p. 245, Pergamon Press(1982)

3 ) Tadros, Th. F. : Advances in Coll, and Inter. Sci. 1 12, 141 (1980)

4 ) Parkhous, K. and Th. F. Tadrous: "Pesticide Science and Biotechnology (6 th ICPC)", p.253, Blackwell Sci. Pub. (1986)

5 ) 和田 譲: 粉体と工業, 18, [8], 34 (1986)

6 ) Wright, J. F. and N. I. Ibraham : Advances in Formulation Technology", p.185, ACS (1984)

7 ) Niessen, J. H. : "Pesticide Chemistry (5th ICPC)", Vol. 4, p.317, Blackwell Sci. Pub. (1982)

8 ) Holley, J. H. : "Pesticide Formulation and Application Systems", p.144, ASTM (1983)

9 ) Gueckel, W. and A. Wigger : Poster Session 4 A/B09 in 6th ICPC (1986)

10) Synek, J. : Poster Session 4D-08 in 6th ICPC (1986)

11) Roechling, K. and R. Heinrich : "Pesticide Science

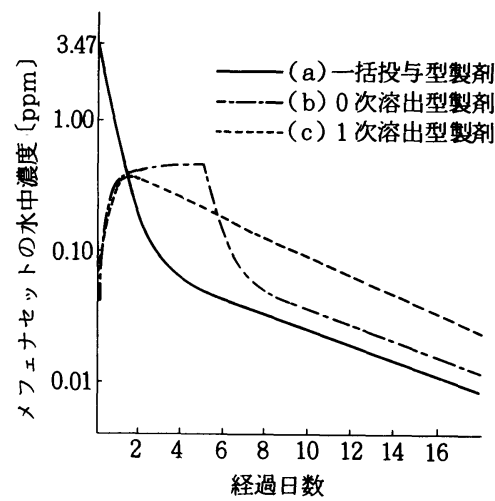

因 7 コンパートメントモデルを用い計算した水田モデルに おける水中メフェナセット濃度

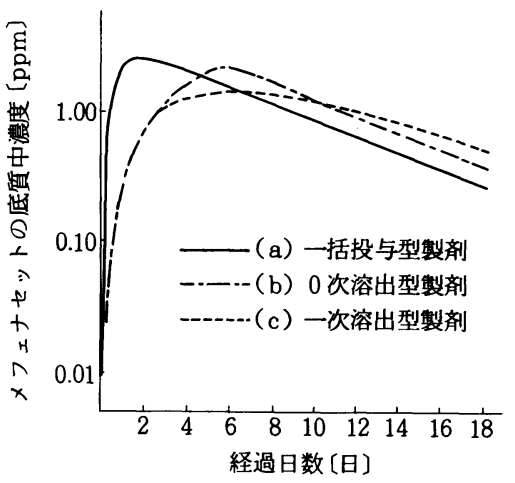

图 8 コンパートメントモデルを用いて計算した水田モデル における底質中メフェナセット嶩度 and Biotechnology (6th ICPC) ${ }^{n}$, p. 269, Blackwell Sci. Pub. (1986)

12) Tsuji, K. and H. Fuyama: "Pesticide Science( 5 th ICPC)", Vol. 4, p.361, Pergamon Press (1982)

13) Wada, Y. and S. Koyama: Poster Session 4D-12 in 6th ICPC (1986)

14) Pimentel, D. and L. Levitan :Biocience, 36, [2], 86 (1986)

15) Maybank, J. : "Pesticide Science and Biotechnolgy (6th ICPC)", p. 243, Blackwell Sci. Pub. (1986)

16) Graham-Bryce, I. J. : Phil. Trans. R. Soc., 281, 163 (1977)

17) Crossland, N. O. and O. Bennet: Pestic. Sci., 17, 297 (1986)

18）鈴木照穈ほか：日本農薬学会第 6 回大回要旨集(1981)

19) Wada, Y., et al. : Pesticide Chemistry", Vol. 4, p. 257 Pergamon Press (1983)

* ICPC : International Congress of Pesticide Chemistry (IUPAC) 